\title{
The renin-angiotensin system in the human eye
}

The circulating renin-angiotensin system (RAS) plays an important role in the control of electrolyte homeostasis and blood pressure. The rate limiting step in the RAS system is the kidney derived enzyme renin, an aspartyl protease, which cleaves its substrate angiotensinogen, a liver derived circulating $\alpha_{2}$ globulin in plasma, to form the decapeptide angiotensin I. Angiotensin $\mathrm{I}$ is then converted by the angiotensin converting enzyme (ACE) to the octapeptide angiotensin II, which stimulates release of aldosterone and constriction of blood vessels. Vasoconstriction has been demonstrated in feline retinal blood vessels exposed to angiotensin $\mathrm{II},{ }^{1}$ and angiotensin binding sites have been found in bovine and human retinal vessels. ${ }^{2} 3$

All of the RAS components are present in the circulating blood and in a number of peripheral tissues, including the human eye. Ophthalmic literature concerning the RAS started in 1977 with a study by Igic and coworkers ${ }^{4}$ on the detection of ACE activity in homogenates of the retina and since then the role of the RAS in the eye has been reported in about 30 publications. Enzyme activities of ACE have been reported further in aqueous humour, vitreous humour, tear fluid, retina, and ciliary body of different species including humans. ${ }^{5-13}$ In rat eyes the enzyme only has been found in the ciliary body but not in the retina. ${ }^{14}$ In dog sphincter pupillae very low ACE activity has been measured. ${ }^{15}$ The presence of angiotensin II has been demonstrated in human ${ }^{1617}$ and feline ${ }^{18}$ vitreous and in pig retina and anterior uveal tract. ${ }^{17}$ Prorenin, the biosynthetic inactive precursor of renin, was detected in human ciliary body ${ }^{19}$ and vitreous humour ${ }^{20}$ at concentrations higher than in plasma. ${ }^{21} 22$ In all segments of bovine eyes the concentration was much too high to be explained by admixture of blood or leakage from the vasculature, ${ }^{23}$ suggesting a local production.

In the above mentioned studies the source of renin and ACE in the eye has not been determined with certainty as apart from local synthesis there is the possibility of selective uptake by the tissues. If the components of the RAS are synthesised locally in the eye, then the gene should be expressed in the ocular tissues. Using polymerase chain reaction (PCR) with renin specific primers and in situ hybridisation with a specific cDNA clone, Wallow et al ${ }^{24}$ and Brandt et al ${ }^{25}$ in 1994 showed that renin mRNA is present in iris, retinal tissue and neural retina, ciliary body, ciliary muscle, and tissue closely related to the outflow channels of the anterior chamber in the rat.

In this issue of the $B \mathcal{O} O$, Wagner et al (p 159) reported their findings in human eyes, using the molecular biology technique of reverse transcription PCR for expression of all components of the RAS in individual eye samples and a RNAse protection assay to detect renin-mRNA in pooled tissue samples. They confirmed gene expression of renin, as was found earlier in the rat, ${ }^{24} 25$ and also found expression of angiotensinogen and ACE in neural retina, retinal pigment epithelium, and choroid; however, no expression was observed in iris and ciliary body. The present study brings the subject closer to the explanation and possible therapy of some human ocular diseases. Activated intraocular RAS may be involved in the development of proliferative diabetic retinopathy. Vitreous levels of angiotensin $\mathrm{II}^{16}$ and of renin ${ }^{21}$ are elevated in patients with diabetic retinopathy and angiotensin II appears to have angiogenic activity, stimulating vessel growth, as shown in a rabbit model of cornea neovascularisation. ${ }^{26}$ Elevated levels of angiotensin II also have been found in an oxygen induced model of proliferative retinopathy in the kitten. ${ }^{18}$ The present paper of Wagner et al supports their earlier conclusion that the elevated vitreous levels of prorenin in diabetic patients are the result of increased synthesis in the retina, ${ }^{21} 23$ because expression of renin mRNA has been found in the retina.

In the pathogenesis of glaucoma, angiotensin induced vascular tone has been implicated as a pathogenic mechanism in glaucomatous cupping and in damage to the optic nerve. ${ }^{2728}$ Regulation of aqueous outflow, and hence intraocular pressure (IOP), occurs in or near the ciliary body and the iris. The evidence for the presence of RAS components necessary for the generation of angiotensin II in this region is suggestive of a local ocular RAS also involved in regulation of IOP. The finding that corneal application of renin inhibitors, ${ }^{29-31}$ and of an ACE inhibitor, ${ }^{32}$ lowers IOP supports such a function. Angiotensin II contracts isolated dog sphincter pupillae via synthesis of cyclo-oxygenase products by acting on specific receptors. 1533

The published data do not distinguish whether activated RAS in the eye is a cause or an effect of the investigated eye diseases. Logically, treatment with enzyme inhibitors, possessing sufficient lipid solubility to cross the blood ocular barriers, seems indicated in prophylaxis or therapy. As already mentioned short term single dose studies of renin inhibitors ${ }^{30}$ and of an ACE inhibitor, ${ }^{31}$ applied as eyedrops in healthy volunteers, showed a decrease in the IOP. Unfortunately, animal models, mimicking proliferative retinopathy and glaucomatous damage to the retina, to evaluate the safety and efficacy of chronic administration of therapeutic agents are not available at present. Whether successful intervention with enzyme inhibitors in the RAS in the eyes of patients suffering from diabetic retinopathy or glaucoma will depend on future clinical trials.

The possibility of undesired side effects, based on the presence of RAS in the neural retina has already been suggested. If the peptide angiotensin II takes the role of transmitter or modulator in retinal neurophysiology, then inhibition of its production might cause disturbance of retinal neuronal function. ${ }^{13}$

N J VAN HAERINGEN

The Netherlands Ophthalmic Research Institute, Amsterdam, Netherlands

1 Rockwood EJ, Fantes F, Davis FB, Anderson DR. The response of retina vasculature to angiotensin. Invest Ophthalmol Vis $S c i$ 1987; 28: 676-82.

2 Ferrari-Dileo G, Davis EB, Anderson DR. Angiotensin binding sites in bovine and human retinal blood vessels. Invest Ophthalmol Vis Sci 1987; 28: $1747-51$

3 Ferrari-Dileo G, Davis EB, Anderson DR. Angiotensin II binding receptors in retinal and optic nerve head blood vessels. An autoradiographic approach. Invest Ophthalmol Vis Sci 1991; 32: 21-6.

4 Igic R, Robinson CJG, Erdös EG. Angiotensin I converting enzyme activity in the choroid plexus and in the retinal. In: Buckley JP, Ferrario CM, eds. Central actions of angiotensin and related hormones. New York: Pergamon Press, 1977: 23-7.

5 Brasil-Vita J, Anderson JA, Hulem CD, Leopold IH. Angiotensin converting enzyme activity in ocular fluids. Invest Ophthalmol Vis Sci 1981; 20: ing en

6 Weinreb RN, Sandman R, Ryder MI, Friberg TR. Angiotensin converting enzyme activity in human aqueous humor. Arch Ophthalmol 1985; 103: 34-6.

7 Ikemoto F, Yamamoto K. Renin angiotensin system in the aqueous humo of rabbits, dogs and monkeys. Exp Eye Res 1978; 27: 723-5.

8 Immonen I, Friberg K, Sorsila R, Fyhrquist F. Concentration of angiotensin converting enzyme in tears of patients with sarcoidosis. Arch Ophthalmol 1987; 65: 27-9.

9 Sharma OP, Brasil-Vita J. Determination of angiotensin converting enzyme in tears: a noninvasive test for evaluation of ocular sarcoidosis. Arch Ophthalmol 1983; 101: 559-61.

10 Thörig L, van Agtmaal EJ, Glasius E, Tan K-L, van Haeringen NJ. Comparison of tears and lacrimal gland fluid in the rabbit and guinea pig. Curr Eye Res 1985; 30: 913-20. 
11 Ward PE, Stewart TA, Hammon KJ, Reynolds RC, Igic R. Angiotensin I converting enzyme (kininase II) in isolated retinal microvessels. Life Sci 1979; 24: 1419-24.

12 Igic $R$, Kojovic V. Angiotensin I converting enzyme (kininase II) in ocular tissues. Exp Eye Res 1980; 30: 299-303.

13 Ferrari-Dileo G, Ryan JW, Rockwood EJ, Davis EB, Anderson DR Angiotensin-converting enzyme in bovine, feline, and human ocular tissues. Invest Ophthalmol Vis Sci 1988; 29: 876-81.

14 Strittmatter SM, Braas KM, Snyder SH. Localisation of angiotensin converting enzyme in the ciliary epithelium of the rat eye. Invest Ophthalmol Vis Sci 1989; 30: 2209-14.

15 Okamura $\mathrm{T}$, Wang $\mathrm{Y}$, Toda $\mathrm{N}$. Local generation and action of angiotensin II in dog iris sphincter muscle. Exp Eye Res 1992; 55: 563-8.

16 Goel AK, Jabbour NM. Vitreous levels of angiotensin II in patients with diabetic retinopathy. Invest Ophthalmol Vis Sci 1991; 32: 1027.

17 Danser AHJ, Derkx FHM, Admiraal PJ, Deinum J, de Jong PTVM, Schalekamp MADH. Angiotensin levels in the eye. Invest Ophthalmol Vis Sci 1994; 35: 1008-18.

18 Schiffman RM, Fisher L, Nussbaum J, Edwards P, Scicli G, Chu J-W. Retinal vascular proliferation and vitreous angiotensin II in the kitten Invest Ophthalmol Vis Sci 1991; 32: 772.

19 Sramek SJ, Wallow IHL, Day RP, Ehrlich EN. Ocular renin-angiotensin immunohistochemical evidence for the presence of prorenin in eye tissue. Invest Ophthalmol Vis Sci 1988; 29: 1749-52.

20 Wallow IHL, Sramek SJ, Bindley CD, Darjatmoko SR, Gange SJ. Ocular renin angiotensin: EM immunocytochemical localisation of pro-renin. Curr Eye Res 1993; 12: 945-50.

21 Danser AHJ, van den Dorpel MA, Deinum J, Derkx FHM, Franken AAM Peperkamp E, et al. Renin, prorenin and immunoreactive renin in vitreous feperkamp E, et al. Renin, prorenin and immunoreactive renin in vitreous fluid from eyes with and

22 Schiffman RM, Fisher L, Nussbaum J, Edwards P, Scicli G. Prorenin and renin levels in the vitreous of human eyes with and without proliferative diabetic retinopathy. Invest Ophthalmol Vis Sci 1992; 33: 1362.
23 Deinum J, Derkx FHM, Danser AHJ, Schalekamp MADH. Identification and quantification of renin and prorenin in the bovine eye. Endocrinology 1990; 126: 1673-82.

24 Wallow IHL, Pumfery AM, Brandt CR, Lyons GE, Micales BK, Sramek SJ, et al. Ocular renin angiotensin: PCR and in situ hybridisation (ISH) show renin synthesis in rat eye. Invest Ophthalmol Vis Sci 1994; 35: 1787.

25 Brandt CR, Pumfery AM, Micales B, Bindley CD, Lyons GE, Sramek SJ, et al. Renin mRNA is synthesized locally in rat ocular tissues. Curr Eye Res 1994; 13: 755-63.

26 Fernandez LA, Twickler J, Mead A. Neovascularisation produced by antiotensin II. $\mathcal{F}$ Lab Clin Med 1985; 105: 141-5.

27 Anderson DR. The posterior segment of glaucomatous eyes. In: LütjenDrecoll E, ed. Basic aspects of glaucoma research. Stuttgart: Schattner, 1982: $167-90$.

28 Anderson DR. The mechanisms of damage to the optic nerve. In Krieglstein GK, Leydhecker W, eds. Glaucoma update II. Berlin: SpringerVerlag, 1983: 89-93.

29 Giardina WJ, Kleinert HD, Ebert DM, Wismer CT, Chekal MA, Stein HH. Intraocular pressure lowering effects of the renin inhibotor ABBOTT64662 diacetate in animals. F Ocul Pharmacol 1990; 6: 75-84.

30 Percicot CL, Mauget M, Pages C. Effects of topical renin inhibitor, CGP 38560 versus timolol on intraocular pressure in normal and ocular hypertensive animal models. Invest Ophthalmol Vis Sci 1995; 36: S719.

31 Denis P, Nordmann JP, Elena PP, Jaillon P, Mathis G, Saraux H. One drop study to evaluate safety and efficacy of SR 43845, a renin inhibitor, in healthy volunteers. Invest Ophthalmol Vis Sci 1995; 36: S734.

32 Constad WH, Fiore P, Samson C, Cinotti AA. Use of an angiotensin converting enzyme inhibitor in ocular hypertension and primary open-angle glaucoma. Am ₹ Ophthalmol 1988; 105: 674-7.

$33 \mathrm{Lu} \mathrm{W}$, Okamura T, Bian K, Inatomi A, Toda N. Prostaglandins involved in contractions by angiotensin II and bradykinin of isolated dog sphincter pupillae. Br f Pharmacol 1988; 95: 544-50. 